\title{
Frequency of Hepatitis B, C and HIV infections among transfusion-dependent Beta
}

\section{Thalassemia patients in Dhaka}

3 Golam Sarower Bhuyan ${ }^{1}$, Aftab Uz Zaman Noor ${ }^{1}$, Rosy Sultana ${ }^{1}$, Farjana Akther Noor ${ }^{2}$, Nusrat

4 Sultana $^{2}$, Suprovath Kumar Sarker ${ }^{2}$, Md Tarikul Islam $^{2}$, Md. Abu Sayeed ${ }^{4}$, Md. Imam Ul Khabir ${ }^{4}$,

5 A K M Ekramul Hossain ${ }^{5}$, Syeda Kashfi Qadri ${ }^{6}$, Syed Saleheen Qadri ${ }^{2}$, Firdausi Qadri ${ }^{1,3}$, Kaiissar

6 Mannoor ${ }^{1,2 *}$

$7{ }^{1}$ Infectious Diseases Laboratory, Institute for Developing Science and Health Initiatives,

8 Mohakhali, Dhaka-1212, Bangladesh

$9{ }^{2}$ Laboratory of Genetics and Genomics, Institute for Developing Science and Health Initiatives,

10 Mohakhali, Dhaka-1212, Bangladesh

$11{ }^{3}$ Department of Enteric and Respiratory Infectious Diseases, Infectious Diseases Division,

12 International Centre for Diarrhoeal Disease Research, Bangladesh, Mohakhali, Dhaka-1212,

13 Bangladesh

$14{ }^{4}$ Mucosal immunology and vaccinology lab, Infectious disease division, International Centre for

15 Diarrhoeal Disease Research, Bangladesh, Mohakhali, Dhaka-1212, Bangladesh.

$16{ }^{5}$ Department of Project Development, Bangladesh Thalassaemia Samity and Hospital, Dhaka-

17 1205, Bangladesh

$18{ }^{6}$ Department of Pediatric Medicine, KK Women's and Children's Hospital, 19 Singapore. 
medRxiv preprint doi: https://doi.org/10.1101/2020.04.28.20079764; this version posted April 29, 2020. The copyright holder for this preprint (which was not certified by peer review) is the author/funder, who has granted medRxiv a license to display the preprint in perpetuity.

It is made available under a CC-BY-ND 4.0 International license .

\section{Acknowledgements}

2 We thank the clinicians and staff of Bangladesh Thalassemia Samity and Hospital for their

3 assistance in specimen collection.

4

5 *Correspondence: Kaiissar Mannoor, address: Institute for Developing Science and Health

6 Initiatives, Mohakhali, Dhaka-1212, Bangladesh, E-mail: kaiissar@ideshi.org, Phone: +88-

$7 \quad 01797440713$

8

9 Keywords: Thalassemia, Transfusion Transmitted Infection, Immunochromatographic (ICT)

10 testing, HBV, HCV.

11

12

13

14

15

16

17

18

19

20 
medRxiv preprint doi: https://doi.org/10.1101/2020.04.28.20079764; this version posted April 29, 2020. The copyright holder for this preprint (which was not certified by peer review) is the author/funder, who has granted medRxiv a license to display the preprint in perpetuity.

It is made available under a CC-BY-ND 4.0 International license .

\section{Author's contribution}

$2 \mathrm{KM}$ and FQ theorized and designed the project. FAN and NS collected patient history. GSB,

3 AUZN, RS, MIUK and SKS performed the experiments. MAS, ZZ, SKQ and AKMEH were

4 involved in data analysis and curation. GSB, AUZN, MTI and SKS wrote the manuscript. Project

5 and manuscript were reviewed by SSQ and MRFS. KM gave final approval of the version to be

6 published.

7

8 Conflict of interest

9 The authors have declared no conflict of interest.

10

11

12

13

14 
medRxiv preprint doi: https://doi.org/10.1101/2020.04.28.20079764; this version posted April 29, 2020. The copyright holder for this preprint

(which was not certified by peer review) is the author/funder, who has granted medRxiv a license to display the preprint in perpetuity.

It is made available under a CC-BY-ND 4.0 International license.

1

\section{Abstract}

2 Transfusion transmitted infections (TTIs) have remained a major deterrent to public health,

3 particularly among the patients with transfusion-dependent Beta thalassemia in developing

4 countries. Although proper donor selection through adoption of WHO-advised infection panel has

5 lowered the rate of infections, the multi-transfused patients are not free of risk. The present study

6 screened 148 transfusion-dependent Beta thalassemia patients to determine the frequency of $\mathrm{HCV}$,

7 HBV and HIV using ELISA method. Among these patients, infected cases with HCV, HBV and

8 HIV were $13.51 \%, 3.37 \%$ and $0 \%$, respectively. Moreover, $2 \%$ of the patients had co-infections

9 with both HBV and HCV. The percentage of infections in the patients with frequent transfusion

10 interval $(\leq 30$ days) was significantly higher $(\mathrm{P}<0.0005)$ than that in the patients with less frequent

11 transfusion intervals (>30 days). Immunochromatography (ICT)-based rapid test kits are usually

12 used to screen and confirm these infections in the blood of the patients. However, ICT-based tests

13 are not sensitive enough to detect the infections. So, a combination of both Nucleic Acid testing

14 (NAT) and serological testing are suggested to significantly reduce the risk of viral infections

15 during blood transfusion. 
medRxiv preprint doi: https://doi.org/10.1101/2020.04.28.20079764; this version posted April 29, 2020. The copyright holder for this preprint (which was not certified by peer review) is the author/funder, who has granted medRxiv a license to display the preprint in perpetuity.

It is made available under a CC-BY-ND 4.0 International license.

\section{Introduction}

Annually, million units of blood are collected from the donors worldwide as the blood transfusion is integral to management of patients suffering from diverse diseases, particularly hematological disorders. From a record of 2013, it has been seen that there were more than 112 million units of blood donation all over the world that year. ${ }^{1}$ Accordingly, transfusion transmitted infections (TTIs) continue to be a major public health issue in many parts of the world and multi-transfused patients of Thalassemia (a group of inherited hemoglobinopathies caused by mutations in the beta globin chain of hemoglobin) are at a particularly increased risk of TTIs. ${ }^{2,3}$ These inherited blood disorders generally occur in the countries of thalassemia belt including Mediterranean and portions of West Africa, North Africa, Middle East and South Asian countries including Bangladesh, India, and Sri Lanka. ${ }^{4}$ As the patients with thalassemia, especially the patients with beta thalassemia major (BTM) and a group of patients with Hemoglobin E-beta thalassemia (EBT) are transfusiondependent and these patients are very much prone to transfusion-transmitted viral infections. After heart failure, viral infections are the second most common cause of mortality and the foremost cause of morbidity among the patients with thalassemia followed by patients with bacterial and parasitic infections. ${ }^{5}$ Although hepatitis B virus (HBV), hepatitis C virus (HCV), human immunodeficiency virus (HIV), West Nile virus (WNV), human T cell lymphotropic viruses I, II (HTLV-I/II) had been reported most frequently, HCV and HBV had been known as the most prevalent etiological agents of chronic viral hepatitis and hepatocellular carcinoma among the thalassemia patients. ${ }^{6}$

In the developed countries, the TTIs risks have been virtually eliminated because of the careful and efficient screening approaches. ${ }^{7}$ However, challenges in developing countries span the entire 
medRxiv preprint doi: https://doi.org/10.1101/2020.04.28.20079764; this version posted April 29, 2020. The copyright holder for this preprint (which was not certified by peer review) is the author/funder, who has granted medRxiv a license to display the preprint in perpetuity.

It is made available under a CC-BY-ND 4.0 International license.

1 blood safety chain from donor selection to post-transfusion surveillance and these risks are really

2 a burning question for public health development. ${ }^{8}$ Bangladesh lies in the global thalassemia belt

3 with around 9,176 new thalassemic patients each year ${ }^{9}$ and the patients with transfusion dependent

$4 \quad$ BTM and EBT undergo regular transfusions with varying degrees of frequencies of transfusions

5 in every 7 to 120 days. However, although it is mandatory, World Health Organization (WHO)-

6 recommended standards for donor blood screening are not always followed in developing

7 countries like Bangladesh due to resource limitations and occasional lack of consciousness. ${ }^{10}$ The

8 patients with transfusion dependent BTM and EBT in Bangladesh not only suffer from various

9 complications for the disease itself, but also due to the lack of proper screening methods of donor

blood, and thus transfusion-transmitted infections are threatening as 'Silent killers'. ${ }^{11}$

12 The minimization of the risks of TTIs highly depends on selection of safe blood donors through

13 screening of the blood using sensitive methods for pathogen detection and such precaution reduces

14 the risk of allogenic blood transfusion. However, transmission of diseases still occurs if there is

15 the inability of the test method to detect the disease in the 'pre-seroconversion' or 'window' phase

16 of their infections, immunologically variant viruses, non-seroconverting chronic or immune-silent

17 carriers and laboratory testing errors. ${ }^{12}$ In the present study, the patients with thalassemia used to

18 visit Bangladesh Thalassemia Samity and Hospital for routine blood transfusion. In the hospital,

19 immunochromatographic tastings (ICTs) were usually performed to detect the presence of a

20 number of common infections in the blood of donors before every transfusion. However, these

21 ICT-based rapid diagnostic test (RDT) kits have not been validated using confirmatory approaches,

22 such as ELISA or molecular methods and usually the ICT-based methods have repeatedly

23 demonstrated low sensitivity and specificity to detect the major TTIs. ${ }^{12,13}$ The present study 
medRxiv preprint doi: https://doi.org/10.1101/2020.04.28.20079764; this version posted April 29, 2020. The copyright holder for this preprint (which was not certified by peer review) is the author/funder, who has granted medRxiv a license to display the preprint in perpetuity.

It is made available under a CC-BY-ND 4.0 International license .

1 investigated the frequency of HBV, HCV and HIV infections among transfusion-dependent beta

2 thalassemia patients of the Thalassemia Samity and Hospital using ELISA method with the aim to

3 explore the efficacy of RDT based screening method.

4

$5 \quad$ Materials and Methods

\section{Study participants}

7 The study enrolled a total of 148 patients with transfusion-dependent Beta thalassemia over a 8 period of 7 months from August 2017 to February 2018. These patients were in the age range of $9 \quad$ 2-46 years (90 patients were $<18$ years). They used to visit Bangladesh Thalassemia Samity and 10 Hospital for follow up examinations and blood transfusions. Both EBT and BTM patients 11 participated in the study and they were all differentially diagnosed by Hemoglobin capillary

12 electrophoresis. The study also included 30 healthy controls (aged 2-46 years) who did not have 13 any previous history of hemoglobinopathies or related blood disorders. Prior to sample collection, 14 a written informed consent was obtained from the adults as well as from the legal guardians of the 15 children (both for the patients and the controls). About 5.0 milliliters of blood were collected from each participant in serum tubes using the standard venipuncture method and serum was separated

17 from the collected blood. In case of patients, blood was collected before transfusion. The study 18 was approved by National Ethics Review Committee (NERC) of Bangladesh Medical Research 19 Council (BMRC), Dhaka, Bangladesh.

Donor blood screening

21 The Bangladesh Thalassemia Samity and Hospital routinely use ICT kits (EXcEL®, USA) for 22 detection of HBV, HCV and HIV in the blood of donors before transfusion. The donor blood was 
medRxiv preprint doi: https://doi.org/10.1101/2020.04.28.20079764; this version posted April 29, 2020. The copyright holder for this preprint (which was not certified by peer review) is the author/funder, who has granted medRxiv a license to display the preprint in perpetuity.

It is made available under a CC-BY-ND 4.0 International license .

1 usually arranged from the hospital services or by the guardian of the patients through their personal

2 contacts or from various blood banks. Every ICT-dependent suspected donor was usually excluded

3 from the transfusion process.

\section{Detection of $\mathrm{HBV}, \mathrm{HCV}$ and $\mathrm{HIV}$ in the blood of patients}

6 As the presence of Hepatitis B surface antigen (HBsAg) in the serum is a good indicator of HBV

7 infections, Bioelisa HBsAg 3.0 kits (Biokit, Barcelona, Spain) were used to detect HBsAg.

8 Bioelisa HCV 4.0 (Biokit, Barcelona, Spain) was used for qualitative detection of anti-HCV

9 antibodies in the sera of the patients. The HIV 1/2/O Antigen/Antibody EIA Test Kit (Acon

10 Laboratories, CA, USA) was used for the qualitative enzyme immunoassay-based detection of

11 HIV-1 P24 antigen and total antibodies (IgG, IgM and IgA) to HIV-1, HIV-2, and/or Subtype O

12 in human serum or plasma. These tests were performed in accordance with the manufacturers'

13 instructions provided with the kits. The color intensity of the final reaction mixture was measured

14 with an ELISA reader (LabSystems Multiskan, USA) at $450 \mathrm{~nm}$.

\section{Statistical analysis}

16 We performed Two-tailed chi-square test (two by two table) using http://www.openepi.com/ to

17 calculate the frequency of infections among the two transfusion interval groups $(\leq 30$ days and $>30$ days). Estimation of the relative risk ratio (RR) and odds ratio (OR) were done at $95 \%$ confidence interval (CI). A P-value of less than 0.05 was considered significant. 
medRxiv preprint doi: https://doi.org/10.1101/2020.04.28.20079764; this version posted April 29, 2020. The copyright holder for this preprint (which was not certified by peer review) is the author/funder, who has granted medRxiv a license to display the preprint in perpetuity.

It is made available under a CC-BY-ND 4.0 International license.

\section{Results}

\section{Demographic characteristics of the patients}

In this study, $53.38 \%$ of the participants were males and $46.62 \%$ were females. There were both BTM and EBT patients among the participants. We recorded different demographic information of the patients like name, address, gender, height, weight, BMI as well as transfusion-related information like age of first transfusion, transfusion interval and number, splenectomy etc. The baseline information of the patients is given in the Table 1.

\section{Trend of infections among the patients}

A total of 22 patients $(14.86 \%)$ with thalassemia were found to be infected (Male: $\mathrm{N}=12,54.54 \%$ and female: $10,45.45 \%)$. Among these 22 infected thalassemia patients, we identified $19(12.83 \%)$ patients infected with either HBV or HCV and 3 (2\%) of them had coinfections with both HBV and HCV. Also, the number of patients infected with $\mathrm{HCV}(\mathrm{N}=20,13.51 \%)$ was higher than that of $\mathrm{HBV}(\mathrm{N}=5,3.37 \%)$ (Table 2). Moreover, none of the patients was infected with HIV and all the healthy controls were negative for HBV, HCV and HIV (data not shown).

\section{Relation of infection frequency with transfusion interval}

We categorized the patients into two groups based on their transfusion interval. One of these groups had the transfusion interval $\leq 30$ days, whereas the other had the transfusion interval of $>30$ days. In the more frequent ( $\leq 30$ days) transfusion group, the number of virally infected patients ( $N$ $=18,25.35 \%)$ was found to be significantly higher $(\mathrm{P}$-value $<0.0005, \mathrm{RR}=1.945$ [1.464 -2.585], $\mathrm{OR}=6.198[1.983-19.37])$ than that of the less frequent $(>30$ days $)$ transfusion group $(\mathrm{N}=4$, $5.19 \%$ ) (Figure 1). 
medRxiv preprint doi: https://doi.org/10.1101/2020.04.28.20079764; this version posted April 29, 2020. The copyright holder for this preprint (which was not certified by peer review) is the author/funder, who has granted medRxiv a license to display the preprint in perpetuity.

It is made available under a CC-BY-ND 4.0 International license.

\section{Discussion}

In Bangladesh Thalassemia Samity and Hospital, effective screening processes for infections are done before blood transfusion for the proper selection of donors. However, still we could identify patients with either HBV or HCV or both. The most important question was why some of the patients got infected albeit standard screening processes were followed before every transfusion.

In case of $\mathrm{HBV}$, there were some asymptomatic donors who were in the 'window period' (i.e. the early infection period when an immunologic test is non-reactive) without any expression of HBsAg. Also, people with occult HBV (absence of HBsAg and the presence of HBV DNA in liver tissues with or without HBV DNA in the serum) may remain undetected by traditional ICT kits. ${ }^{14}$

Previous study also showed that the sensitivity of ICT-based rapid tests was not higher enough to detect hepatitis status of a donor and these kits might not detect certain prevalent serotypes of HBV in any particular region. ${ }^{8}$ Detection of the HBV DNA by implementation of nucleic acid testing (NAT) assays had been reported to shorten the core window period to reduce the residual risk. ${ }^{15}$. In this study, the number of patients infected with HCV was higher than that of HBV. It should be noted here that although there were HBV vaccine coverage to some extent in Bangladesh, there were still no $\mathrm{HCV}$ vaccine available yet. ${ }^{16}$ This may explain why there were more thalassemia patients infected with HCV than with HBV. Rate of infection was found to be significantly higher in the patients who had to undergo frequent transfusions which indicates that multi-transfused thalassemia patients are more prone to infections. This is compatible with previous findings that demonstrated that multiple transfusions receiving for a long period of time might cause immunomodulation resulting in susceptibility to infections. ${ }^{7}$ 
medRxiv preprint doi: https://doi.org/10.1101/2020.04.28.20079764; this version posted April 29, 2020. The copyright holder for this preprint (which was not certified by peer review) is the author/funder, who has granted medRxiv a license to display the preprint in perpetuity.

It is made available under a CC-BY-ND 4.0 International license.

1 In Bangladesh Thalassemia Samity and Hospital, sometimes ELISA methods are applied as a

2 confirmatory test after the donors are suspected as positives by ICT approach. Nevertheless,

3 previous study had shown that ELISA only could detect HBsAg, whereas real-time PCR could

4 represent infection status by detecting HBV-DNA. ${ }^{8}$ On the other hand, recombinant immunoblot

5 assay (RIBA) had more accuracy in detecting HCV. ${ }^{16}$ The multi-transfused patients with

6 thalassemia may face increased immune dysfunction in the presence of iron overload following

7 splenectomy, which makes them more susceptible to infections. ${ }^{17}$ Moreover, in case of emergency,

8 there is a common practice in Bangladesh of risky blood donations by professional donors without

9 any kind of testings who are mostly drug abusers. ${ }^{18}$ Although nowadays an effective awareness in safe blood transfusions and iron chelation therapy have made the morbidity rate of patients with

11 transfusion-dependent Beta thalassemia lower, new complications like hepatocellular carcinoma

12 are taking hold in the patients with thalassemia, which may be due to carcinogenicity of iron

13 overload and chronic infections. ${ }^{19}$ Specially, the thalassemia patients who become co-infected with

14 both $\mathrm{HBV}$ and $\mathrm{HCV}$ are at a greater risk of cirrhosis and hepatocellular carcinoma compared to

15 the mono-infected patients. ${ }^{20}$

17 Hence, there is no alternative of making blood transfusion process safer by proper selection of voluntary healthy blood donors, along with NAT which reveals viral agents earlier in the 'window

19 period' than other immunoassays. Additionally, screening of HBV-DNA and HCV-RNA needs to

20 be practiced regularly to avoid any kind of risks during blood transfusions. ${ }^{17}$ Studies in India,

21 China and Saudi Arabia had reported that NAT-based detection methods for HCV and HBV could

22 tremendously improve the efficacy of screening for protecting blood recipient from TTIs. ${ }^{21-23}$

23 Furthermore, introduction of HBV NAT in the USA, along with the HBV vaccination policy made 
medRxiv preprint doi: https://doi.org/10.1101/2020.04.28.20079764; this version posted April 29, 2020. The copyright holder for this preprint (which was not certified by peer review) is the author/funder, who has granted medRxiv a license to display the preprint in perpetuity.

It is made available under a CC-BY-ND 4.0 International license .

1 a substantial contribution to blood transfusion safety and decreased residual risk of HBV

2 infections. ${ }^{24}$ In the UK, NAT has reduced the risk of HCV by $95 \%$ and that of HIV by $10 \% .{ }^{25}$

3 However, in case of very low levels of viremia, NAT might not be effective enough to detect the

4 infections. Despite the limitations, to ensure safe blood transfusion, combination of both NAT and

5 serological testing may significantly reduce the risk of viral infections during transfusion and thus

6 may improve the quality of life of the thalassemia patients. ${ }^{6}$

8 In this study, we could not compare between serological and NAT-based methods due to budget

9 limitations. Such a comparison could have been a concrete evidence for urging NAT-based

10 screening for blood transfusion in Bangladesh. Moreover, inclusion of other pathogenic organisms

11 in the screening panel could have provided us more information on the severity of the current

12 situation.

14 Conclusion:

15 The patients requiring frequent blood transfusion are more prone to HCV and HBV infections, which can be attributed to unsafe transfusions. To give these patients good quality of life from

17 these preventable complications, efficient screening method for proper donor selection should be

18 adopted in Bangladesh. In addition, awareness should be built to ascertain a safe transfusion. Such

19 practices will ensure a safe blood transfusion for the patients suffering from other diseases and 20 save them from unwanted life-threatening complications. 
medRxiv preprint doi: https://doi.org/10.1101/2020.04.28.20079764; this version posted April 29, 2020. The copyright holder for this preprint

(which was not certified by peer review) is the author/funder, who has granted medRxiv a license to display the preprint in perpetuity.

It is made available under a CC-BY-ND 4.0 International license.

\section{References:}

1. Menitove JE. What is it all about? Transfusion. 2017;57(S2):1585-7.

2. Vidja PJ, Vachhani JH, Sheikh SS, Santwani PM. Blood Transfusion Transmitted Infections in Multiple Blood Transfused Patients of Beta Thalassaemia. Indian J Hematol Blood Transfus. 2011 Jun;27(2):65-9.

3. Islam MT, Sarkar SK, Sultana N, Begum MstN, Bhuyan GS, Talukder S, et al. High resolution melting curve analysis targeting the $\mathrm{HBB}$ gene mutational hot-spot offers a reliable screening approach for all common as well as most of the rare beta-globin gene mutations in Bangladesh. BMC Genetics. 2018 Jan 2;19(1):1.

4. Tahura S. Thalassaemia and other hemoglobinopathies in Bangladeshi children. "Imperial Journal of Interdisciplinary Research (IJIR). 2017 Oct 7;3:180-4.

5. Waheed U, Ahmed Kiani R, Anwar M, Asad M, Zaheer H. Epidemiology of Transfusion Transmitted Infection among Patients with $\beta$-Thalassaemia Major in Pakistan. Journal of Blood Transfusion. 2016 Jul 11;2016.

6. Vento S, Cainelli F, Cesario F. Infections and thalassaemia. Lancet Infect Dis. 2006 Apr;6(4):226-33.

7. Blanco S, Balangero MC, Valle MC, Montini OL, Carrizo LH, Gallego SV. Usefulness of nucleic acid testing to reduce risk of hepatitis B virus transfusion-transmitted infection in Argentina: high rate of recent infections. Transfusion. 2017;57(3pt2):816-22. 
medRxiv preprint doi: https://doi.org/10.1101/2020.04.28.20079764; this version posted April 29, 2020. The copyright holder for this preprint

(which was not certified by peer review) is the author/funder, who has granted medRxiv a license to display the preprint in perpetuity.

It is made available under a CC-BY-ND 4.0 International license.

1 8. Pruett CR, Vermeulen M, Zacharias P, Ingram C, Tayou Tagny C, Bloch EM. The use of rapid diagnostic tests for transfusion infectious screening in Africa: a literature review. Transfus Med Rev. 2015 Jan;29(1):35-44.

9. Noor FA, Sultana N, Bhuyan GS, Islam MT, Hossain M, Sarker SK, et al. Nationwide carrier detection and molecular characterization of $\beta$-thalassemia and hemoglobin $E$ variants in Bangladeshi population. Orphanet Journal of Rare Diseases. 2020 Jan 15;15(1):15.

10. Awan SA, Junaid A, Sheikh S. Transfusion Transmissible Infections: Maximizing Donor Surveillance. Cureus. 2018 Dec 28;10(12):e3787.

11. Saeed M, Hussain S, Rasheed F, Ahmad M, Arif M, Hamid Rahmani MT. Silent killers: Transfusion Transmissible Infections-TTI, among asymptomatic population of Pakistan. J Pak Med Assoc. 2017 Mar;67(3):369-74.

12. Agarwal N, Chatterjee K, Coshic P, Borgohain M. Nucleic acid testing for blood banks: an experience from a tertiary care centre in New Delhi, India. Transfus Apher Sci. 2013 Dec;49(3):482-4.

13. Bloch EM, Shah A, Kaidarova Z, Laperche S, Lefrere J-J, van Hasselt J, et al. A pilot external quality assurance study of transfusion screening for HIV, HCV and HBsAG in 12 African countries. Vox Sang. 2014 Nov;107(4):333-42.

14. Laperche S, Francophone African Group for Research in Blood Transfusion. Multinational assessment of blood-borne virus testing and transfusion safety on the African continent. Transfusion. 2013 Apr;53(4):816-26. 
medRxiv preprint doi: https://doi.org/10.1101/2020.04.28.20079764; this version posted April 29, 2020. The copyright holder for this preprint

(which was not certified by peer review) is the author/funder, who has granted medRxiv a license to display the preprint in perpetuity.

It is made available under a CC-BY-ND 4.0 International license.

1 15. Keechilot CS, Shenoy V, Kumar A, Biswas L, Vijayrajratnam S, Dinesh K, et al. Detection

2 of occult hepatitis B and window period infection among blood donors by individual

3 donation nucleic acid testing in a tertiary care center in South India. Pathog Glob Health.

42016 Dec;110(7-8):287-91.

16. Ahmed MU, Begum HA, Hossain T, Chakraborty P. Incidence of Common Transfusion Transmitted Diseases Among Blood Donors. Journal of Armed Forces Medical College, Bangladesh. 2009;5(1):4-6.

17. Choudhry VP. Hepatitis B and C Infections in Multitransfused Thalassemic Patients. Indian J Pediatr. 2015 Mar 1;82(3):212-4.

18. Mollah AH, Nahar N, Siddique MdA, Anwar KS, Hassan T, Azam MdG. Common Transfusion-transmitted Infectious Agents among Thalassaemic Children in Bangladesh. Journal of Health, Population and Nutrition. 2003;21(1):67-71.

19. Moukhadder HM, Halawi R, Cappellini MD, Taher AT. Hepatocellular carcinoma as an emerging morbidity in the thalassemia syndromes: A comprehensive review. Cancer.

20. Konstantinou D, Deutsch M. The spectrum of HBV/HCV coinfection: epidemiology, clinical $2017 ; 123(5): 751-8$. immunodeficiency virus-1, hepatitis $\mathrm{C}$ virus and hepatitis B virus and its role in blood safety. Asian J Transfus Sci. 2015;9(2):199-202. 
1 22. Dong J, Wu Y, Zhu H, Li G, Lv M, Wu D, et al. A pilot study on screening blood donors with individual-donation nucleic acid testing in China. Blood Transfus. 2014 Apr;12(2):1729.

23. Alaidarous M, Choudhary RK, Waly MI, Mir S, Bin Dukhyil A, Banawas SS, et al. The prevalence of transfusion-transmitted infections and nucleic acid testing among blood donors in Majmaah, Saudi Arabia. Journal of Infection and Public Health. 2018 Sep 1;11(5):702-6. nucleic acid testing: does it improve blood safety? Transfusion. 2013;53(10pt2):2449-58.

25. Soldan K, Barbara J a. J, Ramsay ME, Hall AJ. Estimation of the risk of hepatitis B virus, hepatitis $\mathrm{C}$ virus and human immunodeficiency virus infectious donations entering the blood supply in England, 1993-2001. Vox Sanguinis. 2003;84(4):274-86. 
medRxiv preprint doi: https://doi.org/10.1101/2020.04.28.20079764; this version posted April 29, 2020. The copyright holder for this preprint (which was not certified by peer review) is the author/funder, who has granted medRxiv a license to display the preprint in perpetuity.

It is made available under a CC-BY-ND 4.0 International license .

1 Table 1. Baseline information of the patients enrolled in this study

\begin{tabular}{|l|l|}
\hline \multicolumn{1}{|c|}{ Parameters } & \\
\hline Gender & Male, N=79 (53.38\%); Female, N=69 (46.62\%) \\
\hline Thalassemia type & EBT, N=90 (60.81\%); BTM, N=58 (39.18\%) \\
\hline Age (years), mean \pm SD & $17.15 \pm 9.33$ \\
\hline BMI $\left(\mathrm{kg} / \mathrm{m}^{2}\right)$, mean $\pm \mathrm{SD}$ & $17.39 \pm 3.32$ \\
\hline Transfusion interval (days), mean \pm SD & $33.68 \pm 29.98$ \\
\hline Transfusion number, mean \pm SD & $228.32 \pm 189.85$ \\
\hline Splenomegaly $(\mathrm{cm})$, mean \pm SD & $6.94 \pm 3.09$ \\
\hline Splenectomy & $\mathrm{N}=21(14.18 \%)$ \\
\hline (Abbreviations: EBT= HbE Beta Thalassemia, BTM= Beta Thalassemia Major, SD= Standard Deviation, BMI= Body Mass Index)
\end{tabular}

3 Table 2. Frequency of viral mono-infection and co-infection among the transfusion4 dependent EBT and BTM patients

\begin{tabular}{|c|c|c|c|c|c|}
\hline \multirow{2}{*}{$\begin{array}{l}\text { Thalassemia } \\
\text { type }\end{array}$} & \multicolumn{4}{|l|}{ Infection Type } & \multirow{2}{*}{$\begin{array}{l}\text { No. of } \\
\text { Total } \\
\text { infected } \\
(\%)\end{array}$} \\
\hline & $\begin{array}{l}\text { No. of patients } \\
\text { with HBV and } \\
\text { HCV }(\%)\end{array}$ & $\begin{array}{l}\text { No. of } \\
\text { patients with } \\
\text { HBV }(\%)\end{array}$ & $\begin{array}{l}\text { No. of } \\
\text { patients with } \\
\mathrm{HCV}(\%)\end{array}$ & $\begin{array}{l}\text { No. of } \\
\text { patients with } \\
\text { HIV }(\%)\end{array}$ & \\
\hline $\operatorname{EBT}(\mathrm{N}=90)$ & $1(1.11)$ & $2(2.22)$ & $11(12.22)$ & $0(0)$ & $14(15.55)$ \\
\hline BTM $(\mathrm{N}=58)$ & $2(3.44)$ & $0(0)$ & $6(10.34)$ & $0(0)$ & $8(13.79)$ \\
\hline Total $(\mathrm{N}=148)$ & $3(2.02)$ & $2(1.35)$ & $17(11.48)$ & $0(0)$ & $22(14.86)$ \\
\hline
\end{tabular}


medRxiv preprint doi: https://doi.org/10.1101/2020.04.28.20079764; this version posted April 29, 2020. The copyright holder for this preprint (which was not certified by peer review) is the author/funder, who has granted medRxiv a license to display the preprint in perpetuity. It is made available under a CC-BY-ND 4.0 International license.

1

(Abbreviations: $\mathrm{EBT}=\mathrm{E}$ Beta Thalassemia, BTM= Beta Thalassemia Major, HBV= Hepatitis B Virus, HCV= Hepatitis C Virus, HIV= Human

Immunodeficiency Virus) 


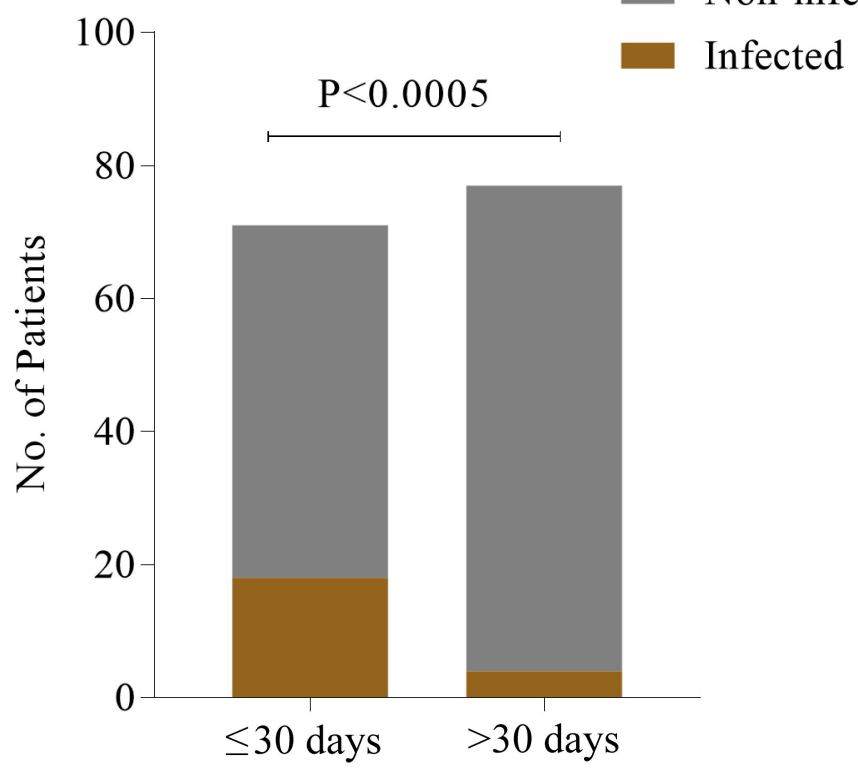

